\section{Sanford-Burnham goes fourth}

\section{By Michael J. Haas, Senior Writer}

Sanford-Burnham Medical Research Institute's outreach to industry has resulted historically in deals focused either on a narrow range of projects or the work of individual investigators, but the institute also has been seeking broader partnerships that tap both its basic research and drug discovery expertise. Its new deal with Daiichi Sankyo Co. Ltd. is its most expansive to date in terms of the range of projects and number of faculty members it will encompass.

Sanford-Burnham's expanding approach to industry partnerships contrasts with that of The Scripps Research Institute, which has moved away from the institute-wide agreements it had previously maintained with pharma. ${ }^{1,2}$

Under the three-year deal, Sanford-Burnham will conduct preclinical studies to identify and validate new cardiovascular and metabolic disease targets. Researchers from the institute and Daiichi Sankyo's CardiovascularMetabolics Research Laboratories will perform screening to identify new compounds against those targets.

"We are escalating our pharma partnering efforts as part of our new 10 -year plan" to speed the development and licensing of preclinical therapies, said Leslie Molony, the institute's senior director of business development.
The plan was announced this year and involves closer collaborations with existing partners, the formation of disease-focused teams to expand the internal cross talk between labs and clinics, and using the institute's small molecule drug discovery platform to validate preclinical candidates that could be licensed to pharmas. ${ }^{3}$

Indeed, Sanford-Burnham approached Daiichi and introduced it to the institute's resources and capabilities in March 2013, Molony said.

The pharma's decision to enter a collaboration "was based on a combination of several factors, including the number of key opinion leaders we have in cardiovascular and metabolic diseases and the capacity of the institute's Conrad Prebys Center for Chemical Genomics to conduct screening and drug discovery," she said.

Another factor influencing Daiichi's decision is the existing partnerships that Sanford-Burnham's Lake Nona campus in Orlando, Fla., has with Florida Hospital and The Translational Research Institute for Metabolism and Diabetes (TRI). Those deals, said Molony, could enable future translational research by giving Daiichi access to clinical resources.

TRI is a 2009 joint venture between Sanford-Burnham and Florida Hospital that gives the institute access to patients in the clinic and fosters cross talk between clinical and preclinical researchers. ${ }^{4}$

Sanford-Burnham and Daiichi have selected an undisclosed subset of cardiovascular and metabolic diseases to study, and a joint steering committee will choose specific projects. Molony said that all Sanford-Burnham researchers working in cardiovascular and/or metabolic diseases are free to propose their projects as candidates to the joint steering committee. Although not the institute's first pharma collaboration that is open to all comers, "this partnership with Daiichi Sankyo engages both our high-impact biomedical research and drug discovery capabilities and integrates the two in ways we have not been able to do in the past," she said.

Ownership of any new IP generated by the collaborators would be assigned to whichever party invents it, she said. The collaboration will

Table 1. Daiichi Sankyo's cardiovascular and endocrine/metabolic disease pipelines. The therapies that Daiichi Sankyo Co. Ltd. (Tokyo:4568) has in its pipelines to treat cardiovascular or endocrine/metabolic diseases may hint at the indications for which the pharma seeks to identify new targets and small molecule therapies through its partnership with the Sanford-Burnham Medical Research Institute.

Source: BCIQ: BioCentury Online Intelligence

\begin{tabular}{|c|c|c|c|}
\hline Product & Description & Status & Partners \\
\hline \multicolumn{4}{|c|}{ Cardiovascular disease pipeline } \\
\hline Benicar/Olmec olmesartan & $\begin{array}{l}\text { Angiotensin II type } 1 \text { receptor } \\
\text { (AGTR1) antagonist }\end{array}$ & Marketed for hypertension & Pfizer Inc. (NYSE:PFE) \\
\hline $\begin{array}{l}\text { Azor/Sevikar } \\
\text { olmesartan/amlodipine }\end{array}$ & $\begin{array}{l}\text { Fixed-dose combination of olmesartan } \\
\text { and amlodipine, a dihydropyridine } \\
\text { calcium channel blocker }\end{array}$ & Marketed for hypertension & Not applicable \\
\hline $\begin{array}{l}\text { Benicar HCT } \\
\text { olmesartan/hydrochlorothiazide }\end{array}$ & $\begin{array}{l}\text { Fixed-dose combination of olmesartan } \\
\text { and hydrochlorothiazide, a diuretic }\end{array}$ & Marketed for hypertension & Not applicable \\
\hline $\begin{array}{l}\text { Tribenzor/Sevikar HCT } \\
\text { olmesartan/amlodipine/ } \\
\text { hydrochlorothiazide }\end{array}$ & $\begin{array}{l}\text { Fixed-dose combination of olmesartan, } \\
\text { amlodipine and hydrochlorothiazide }\end{array}$ & Marketed for hypertension & Not applicable \\
\hline Effient prasugrel & $\begin{array}{l}\text { Purinergic receptor P2Y G protein- } \\
\text { coupled } 12 \text { (P2RY12; P2Y12) } \\
\text { antagonist }\end{array}$ & $\begin{array}{l}\text { Marketed for acute coronary } \\
\text { syndrome; approved for ischemia/ } \\
\text { reperfusion injury }\end{array}$ & Eli Lilly and Co. (NYSE:LLY) \\
\hline Lixiana edoxaban & Oral factor Xa inhibitor & $\begin{array}{l}\text { Marketed for venous } \\
\text { thromboembolism; in registration } \\
\text { for fibrillation }\end{array}$ & Not applicable \\
\hline
\end{tabular}


Table 1. Daiichi Sankyo's cardiovascular and endocrine/metabolic disease pipelines. (continued)

\begin{tabular}{|c|c|c|c|}
\hline Product & Description & Status & Partners \\
\hline \multirow{2}{*}{$\begin{array}{l}\text { Collategene beperminogene } \\
\text { perplasmid (AMG0001; HGF } \\
\text { gene therapy) }\end{array}$} & \multirow{2}{*}{$\begin{array}{l}\text { Plasmid encoding human hepatocyte } \\
\text { growth factor/scatter factor (HGF/SF) }\end{array}$} & $\begin{array}{l}\text { Phase III for ischemia/reperfusion } \\
\text { injury }\end{array}$ & $\begin{array}{l}\text { Vical Inc. (NASDAQ:VICL); AnGes MG Inc. } \\
\text { (Tokyo:4563) }\end{array}$ \\
\hline & & $\begin{array}{l}\text { Phase III for peripheral vascular } \\
\text { disease }\end{array}$ & $\begin{array}{l}\text { Vical; AnGes MG; Mitsubishi Tanabe Pharma } \\
\text { Corp. (Tokyo:4508) }\end{array}$ \\
\hline CS-3150 (XL550) & $\begin{array}{l}\text { Small molecule antagonist of the } \\
\text { mineralocorticoid receptor }\end{array}$ & Phase II for hypertension & Exelixis Inc. (NASDAQ:EXEL) \\
\hline \multicolumn{4}{|c|}{ Endocrine/metabolic disease pipeline } \\
\hline $\begin{array}{l}\text { Sapropterin hydrochloride } \\
\text { (Biopten Granules } 10 \% \text { ) }\end{array}$ & $\begin{array}{l}\text { Chemically synthesized form of natural } \\
\text { tetrahydrobiopterin (THB; } \mathrm{BH} 4 \text { ) }\end{array}$ & Marketed for phenylketonuria & Not applicable \\
\hline $\begin{array}{l}\text { Kuvan sapropterin } \\
\text { hydrochloride }\end{array}$ & $\begin{array}{l}\text { Small molecule formulation of } \\
\text { tetrahydrobiopterin }\end{array}$ & Marketed for phenylketonuria & $\begin{array}{l}\text { BioMarin Pharmaceutical Inc. } \\
\text { (NASDQ:BMRN); Merck KGaA (Xetra:MRK) }\end{array}$ \\
\hline Tenelia teneligliptin & $\begin{array}{l}\text { Dipeptidyl peptidase-4 (DPP-4; CD26) } \\
\text { inhibitor }\end{array}$ & Marketed for type 2 diabetes & $\begin{array}{l}\text { Mitsubishi Tanabe Pharma; Handok Inc. } \\
\text { (KSE:002390) }\end{array}$ \\
\hline Invokana canagliflozin & $\begin{array}{l}\text { Sodium-glucose cotransporter } 2 \\
\text { (SGLT2) inhibitor }\end{array}$ & Marketed for type 2 diabetes & $\begin{array}{l}\text { Mitsubishi Tanabe Pharma; Johnson \& } \\
\text { Johnson (NYSE:JNJ) }\end{array}$ \\
\hline Fastic/Starlix nateglinide & $\begin{array}{l}\text { D-Phenylalanine amino acid derivative } \\
\text { that blocks ATP-dependent potassium } \\
\text { channel (KATP) }\end{array}$ & $\begin{array}{l}\text { Marketed to prevent or treat type } 2 \\
\text { diabetes }\end{array}$ & $\begin{array}{l}\text { Novartis AG (NYSE:NVS; SIX:NOVN); } \\
\text { Ajinomoto Co. Inc. (Tokyo:2802); Astellas } \\
\text { Pharma Inc. (Tokyo:4503) }\end{array}$ \\
\hline \multirow{2}{*}{$\begin{array}{l}\text { Cholestagel/Welchol } \\
\text { colesevelam }\end{array}$} & \multirow[b]{2}{*}{ Nonabsorbed bile acid sequestrant } & Marketed for type 2 diabetes & Sanofi (Euronext:SAN; NYSE:SNY) \\
\hline & & Marketed for hypercholesterolemia & $\begin{array}{l}\text { Sanofi; Valeant Pharmaceuticals } \\
\text { International Inc. (TXS:VRX; NYSE:VRX) }\end{array}$ \\
\hline Benicar/Olmec olmesartan & AGTR1 antagonist & Phase III for diabetes & Not applicable \\
\hline DS-1150 & $\begin{array}{l}\text { Solute carrier family } 2 \text { facilitated } \\
\text { glucose transporter member } 4 \\
\text { (SLC2A4; GLUT4) translocation } \\
\text { enhancer }\end{array}$ & Phase I for diabetes & Not applicable \\
\hline DS-1442 & $\begin{array}{l}\text { Cholesteryl ester transfer protein } \\
\text { (CETP) inhibitor }\end{array}$ & Phase I for dyslipidemia & Not applicable \\
\hline DS-7309 & Glucokinase (GCK; GK) activator & Phase I for diabetes & Not applicable \\
\hline DS-8500 & $\begin{array}{l}\text { G protein-coupled receptor } 119 \\
\text { (GPR119) agonist }\end{array}$ & Phase I for diabetes & Not applicable \\
\hline
\end{tabular}

focus on projects only as far as lead optimization. If Daiichi Sankyo wants to continue developing a project beyond that stage, it would do so in-house. Financial details of the partnership are undisclosed.

Daiichi markets or co-markets at least 12 therapies to treat cardiovascular or metabolic indications and is developing or co-developing at least 6 other clinical-stage therapies between the 2 disease areas (see Table 1, "Daiichi Sankyo's cardiovascular and endocrine/metabolic disease pipelines").

\section{Four now}

Daiichi Sankyo is the institute's fourth pharma partner in as many years.

In 2010, Sanford-Burnham and TRI partnered with Takeda Pharmaceutical Co. Ltd. to support the clinical development of an undisclosed obesity compound from the pharma. ${ }^{4}$ The two institutes renewed the deal with Takeda last year. ${ }^{5}$

In 2011, Sanford-Burnham signed two pharma deals: a three-year partnership with the Ortho-McNeill-Janssen Pharmaceutical Inc. unit of Johnson \& Johnson to develop therapeutics against new targets in Alzheimer's disease (AD) and other neuropsychiatric indications, ${ }^{6}$ and a partnership with Pfizer Inc. to discover mechanisms and therapies for undisclosed diseases under the pharma's Global Centers for Therapeutic Innovation initiative. ${ }^{7}$ According to Molony, the 2011 partnership with Pfizer was the institute's first that was open to all comers.
In 2013, Sanford-Burnham entered into a separate partnership with Pfizer to identify and validate targets to prevent and treat insulin resistance and organ damage in obesity-related diabetes. Under the three-year deal, the pharma is using the institute's Conrad Prebys Center for Chemical Genomics to conduct high throughput screening for new targets using investigational compounds from Pfizer and a compound library from the NIH. ${ }^{5}$

In January, Sanford-Burnham announced that it had received an anonymous $\$ 275$ million gift to fund its 10 -year drug development plan. The institute expects to raise another $\$ 225$ million for the plan from philanthropists, investors and other sources over the next decade. $^{3}$

Daiichi Sankyo did not respond to requests for comment.

Haas, M.J. SciBX 7(22); doi:10.1038/scibx.2014.633

Published online June 5, 2014

REFERENCES

1. Osherovich, L. SciBX 5(3); doi:10.1038/scibx.2012.61

2. Cain, C. SciBX 7(17); doi:10.1038/scibx.2014.477

3. Haas, M.J. SciBX 7(6); doi:10.1038/scibx.2014.160

4. Haas, M.J. SciBX 4(16); doi:10.1038/scibx.2011.446

5. Haas, M.J. SciBX 6(33); doi:10.1038/scibx.2013.880

6. Cain, C. SciBX 4(5); doi:10.1038/scibx.2011.123

7. Cain, C. SciBX 3(46); doi:10.1038/scibx.2010.1371

COMPANIES AND INSTITUTIONS MENTIONED

Daiichi Sankyo Co. Ltd. (Tokyo:4568), Tokyo, Japan 


\section{ANALYSIS}

Florida Hospital, Orlando, Fla.

Johnson \& Johnson (NYSE:JNJ), New Brunswick, N.J.

National Institutes of Health, Bethesda, Md.

Pfizer Inc. (NYSE:PFE), New York, N.Y.

Sanford-Burnham Medical Research Institute, La Jolla, Calif.

\section{TRANSLATIONAL NOTES}

The Scripps Research Institute, La Jolla, Calif.

Takeda Pharmaceutical Co. Ltd. (Tokyo:4502), Osaka, Japan

The Translational Research Institute for Metabolism and

Diabetes, Winter Park, Fla. 